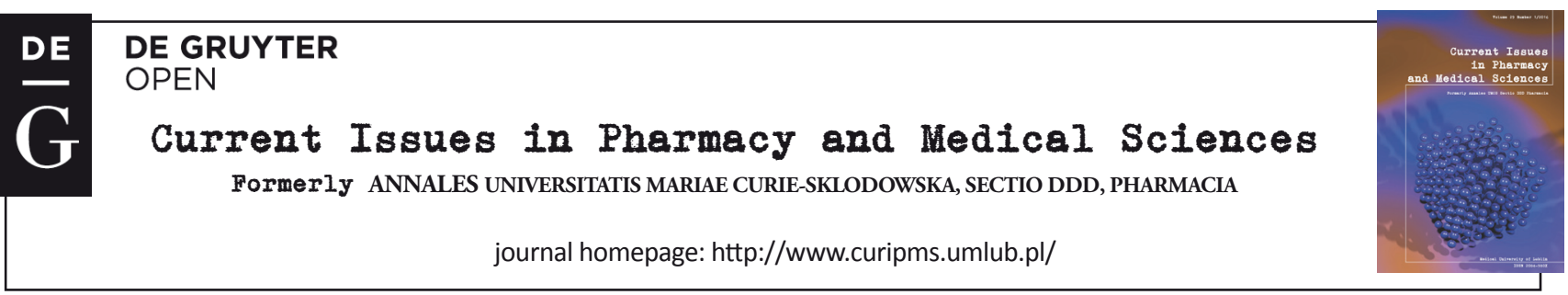

\title{
The history of pharmacy in Adamów
}

\author{
Andrzej Wrobel ${ }^{1}$, Malgorzata Korzeniowska ${ }^{1 \star}$, Agnieszka Polak ${ }^{1}$, \\ Marcin SzCZYGIEL ${ }^{1}$, RAFAL WrobeL ${ }^{2}$ \\ ${ }^{1}$ Department of History of Medicine, Medical University of Lublin, Poland \\ ${ }^{2}$ Chair and Department of Paedodontics, Medical University of Lublin, Poland
}

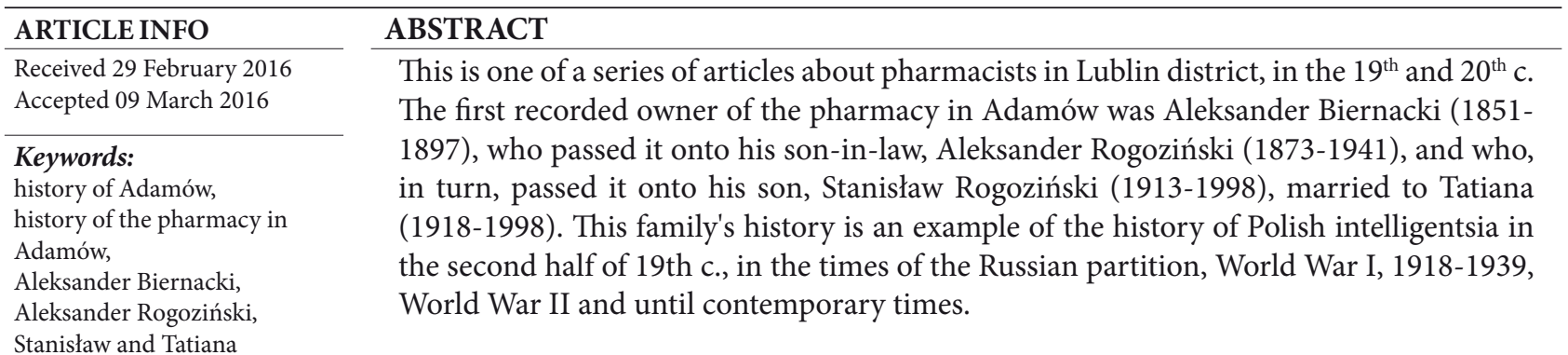

Rogozińscy.

\section{INTRODUCTION}

\section{The short history of Adamów}

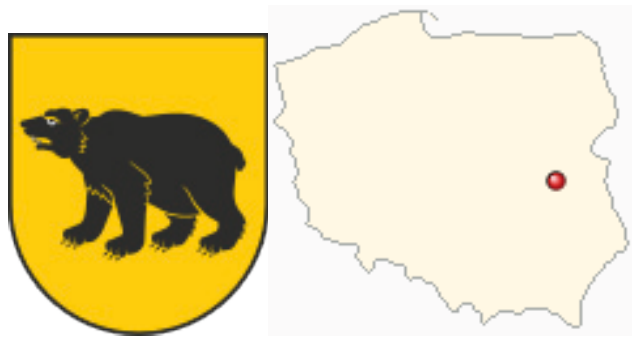

(source: http://www.adamow.eu/index.php?option=com_content\&view=arti cle\&id=6\&Itemid $=9$ )

Figure 1. Adamów's Coat of Arms is of a bear standing on four paws. The bear has turned his muzzle to the right. The bear was the emblem of Rusiecki family, who were the first owners of village

Adamów is a village in eastern Poland, near the small towns of Łuków and Kock, and it has a long historical tradition $[1,2,16,17,19]$. It was founded in 1539 , by the Polish noble family, Rusiecki, upon gaining a permit to do so from Sigmund I, the king of Poland in the years 15061548. Owing to the high position and influence of the Rusiecki's family in the contemporary society, Adamów was soon granted a municipal charter which guaranteed special rights and privileges: a Mayor's Office, three jurors, the right to hold fairs and markets. During the $18^{\text {th }}$ and $19^{\text {th }}$ centuries, the town belonged to the Krasiński and Czartoryski families [16,20]. In 1869, due to oppressive policy of the

\footnotetext{
* Corresponding author

e-mail: mkorzeniowska888@gmail.com
}

Russian authorities, it lost its municipality rights. Still, at the beginning of the $20^{\text {th }}$ century, the people who lived in Adamów showed their entrepreneurial spirit and started up several cooperative societies, as well as a village library. Between 1864 and 1918, the demographic structure of Adamów changed, and the village population increased from 289 Poles (Catholics), 283 Jews and 5 Russians (Orthodox Church) in 1890, to 1073 Poles, 647 Jews, 14 Russians and 6 Germans and 21 Serbs in 1918 [21]. This multicultural society lasted until World War II, when the Nazi authorities herded Adamów's Jewish community first into the ghetto in Łuków, and then, in 1942, to Treblinka Death Camp $[15,16,26]$. At the beginning of World War II, in September 1939, near Adamów, several skirmishes came about between the Polish soldiers and the German invaders. In 1943, almost all the center of Adamów was burnt-out, including the office building of the municipality, the school and the pharmacy [16]. Despite their abhorrent situation, the inhabitants of Adamów tried to keep their language and culture alive, and organized aid to the unfortunate, established and ran secret schools, and even held theatrical performances. The Nazi occupation of Nazi ended in 1944, and the villagers rolled up their sleeves and began to rebuild their home.

Aleksander Biernacki, Aleksander and Maria Rogozińscy, as well as their son Stanisław Rogoziński with his wife Tatiana played a very important role in the history of Adamów. Like many Polish pharmacists, they represented the highest moral standards of the land. They aided their poorer neighbours, and took a prominent part in village society. 


\section{THE HISTORY OF PHARMACY IN ADAMÓW}

\section{Aleksander Biernacki (1851-1897), the founder of pharmacy in Adamów}

The Administrative Council of the Kingdom of Poland issued an Act of Law for pharmacists and pharmacies in 1844. The Act determined the requirements for the staff, the procedures for the establishment, sale and lease of pharmacies. Furthermore, it determined the rights and duties of pharmacists, it also described the basic equipment of pharmacies, the rules for the sale of drugs, as well as the issues of supervision and inspection of the pharmacies. The earliest reports on the history of the pharmacy in Adamów goes back around 1882, when Aleksander Biernacki bought the pharmacy in Adamów in the building in Śniegocki Square (the contemporary name). This building still exists and now houses a bank. The pharmacy was in the hands of family of Aleksander Biernacki till 1982.

We do not have much information about the life of Aleksander Biernacki. Yet, as the owner of the pharmacy, he must have held a very important role in the history of Adamów. In these times, a pharmacy played the role of a first-aid post and health centre to the local people, hence, pharmacists

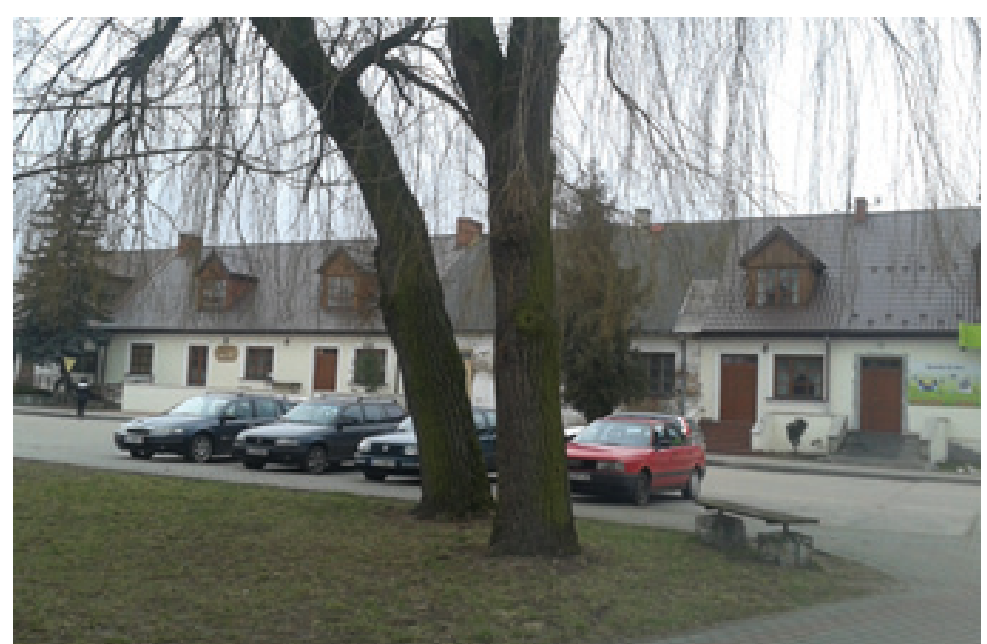

Figure 3. The pharmacy in Kleberga Street where the pharmacy has been situated since 1990 (Source: Photo Małgorzata Korzeniowska, 2015)
Figure 2. The pharmacy in Adamów was situated in this building in the years 1882-1989. It was not all the time in the same place, after the fire in April 1943, it was moved from the left, to the central part of the building (which is currently undergoing renovation)

(Source: Photo Małgorzata Korzeniowska, 2015)
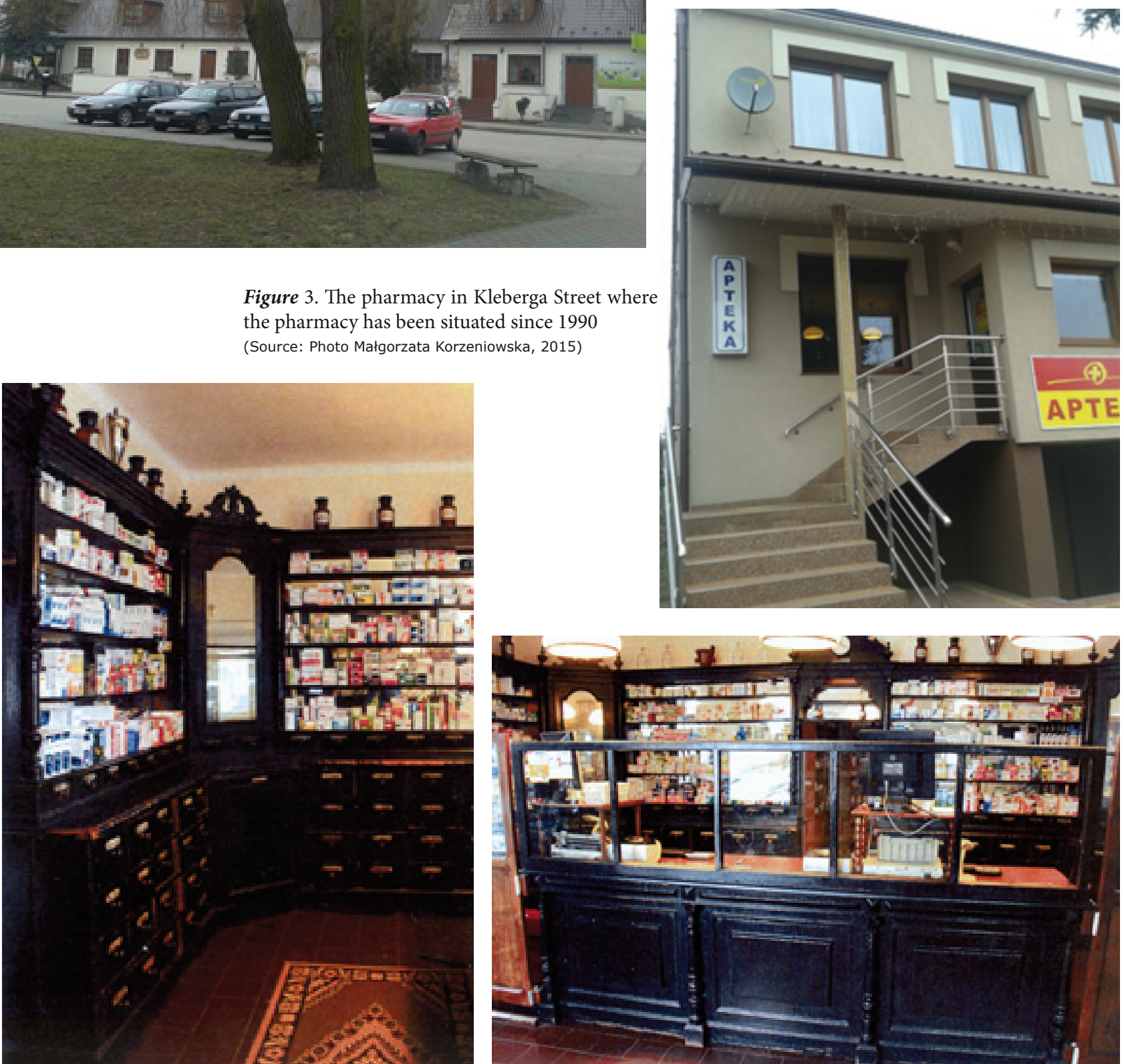

Figure 4,5. The original furniture from the old pharmacy belonging to Biernacki family is now in the pharmacy in Kleberga Street which belongs to Marianna Suska-Mazur M. Pharm.

(collection of Marianna Suska-Mazur) 
often gave advice on health problems and bound wounds. Of note, there is information that the great Polish writer and Nobel Prize winner, Henryk Sienkiewicz was a client [2].

Aleksander Biernarcki worked as a pharmacist for 15 years. He had a daughter Maria, and he died on 12 November 1897, at the age of 46.

\section{Aleksander Rogoziński (1873-1941)}

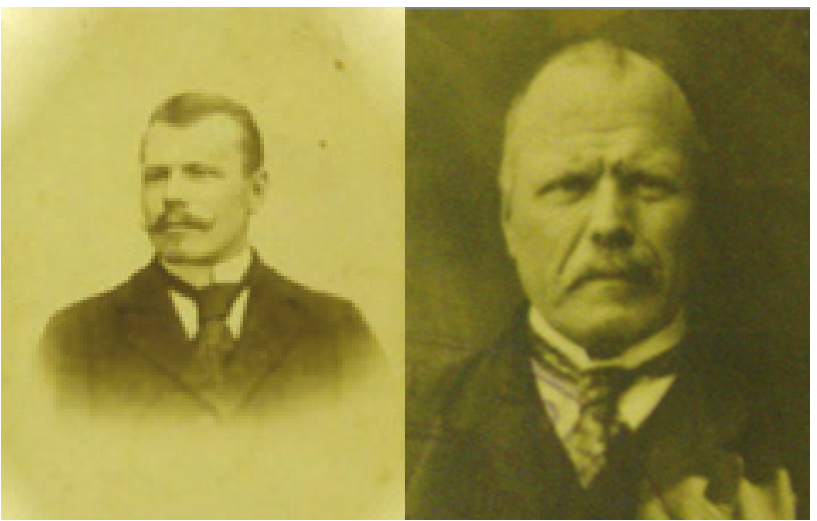

Figure 6, 7. Aleksander Rogoziński (1873-1941)

(Source: Private collection of the Rogoziński's family)

Aleksander Rogoziński was born on 14 May 1873, in Solec Kujawski [18]. In 1891, he began his apprenticeship in the pharmacy in Opatów, and he formally began studying pharmacy at the University of Dorpat (at present Tartu, Estonia) in 1897, graduating from the Imperial University of Warsaw with a Master Degree in Pharmacy in 1904 [14].

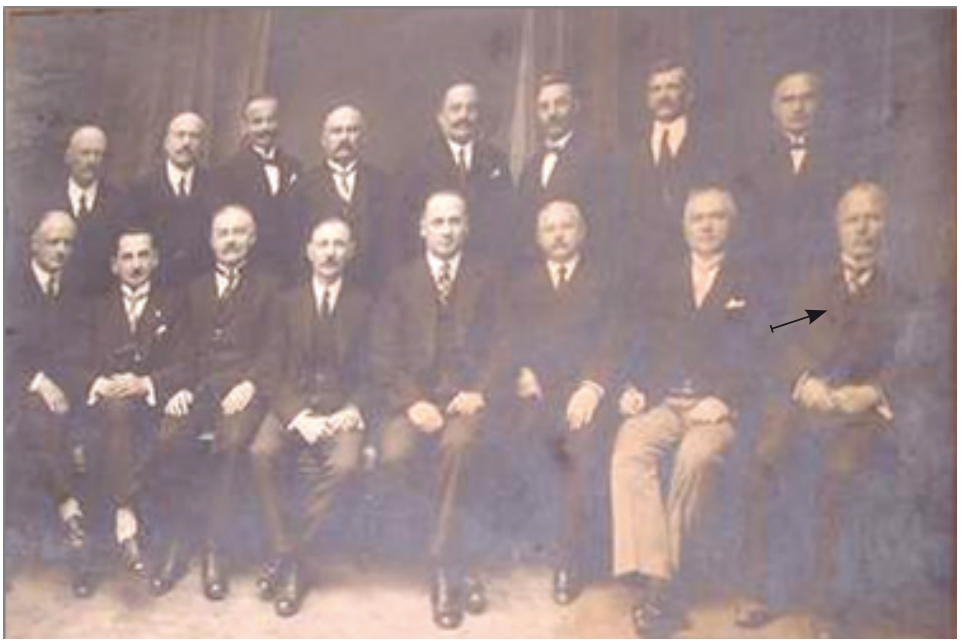

Aleksander and Maria had three children: Marianna, Martyna and Stanisław. As a very important person in the local community, Aleksander Rogoziński was a member of volunteer fire department, a co-founder of the Polish credit union "Kasa Stefczyka", as well as a member, and, indeed, the treasurer of the Polish Pharmaceutical Society in Lublin [1,25]. During World War II, he joined the Polish resistance movement, fighting in the Home Army (AK). He, with a group of local intelligentsia, was arrested for his activity by the Nazis in 14 September 1940 in Adamów [15]. He was imprisoned in Radzyń Podlaski, and in the castle of Lublin. Aleksander Rogoziński was transferred to Auschwitz Concentration Camp in January 1941, where he died in 31 March 1941. The official information to the family was that he died of pneumonia [1], but, in fact, the death of prisoners in concentration camps was due to starvation and hard work.

After his death, the pharmacy was inherited by his son Stanisław Rogoziński.

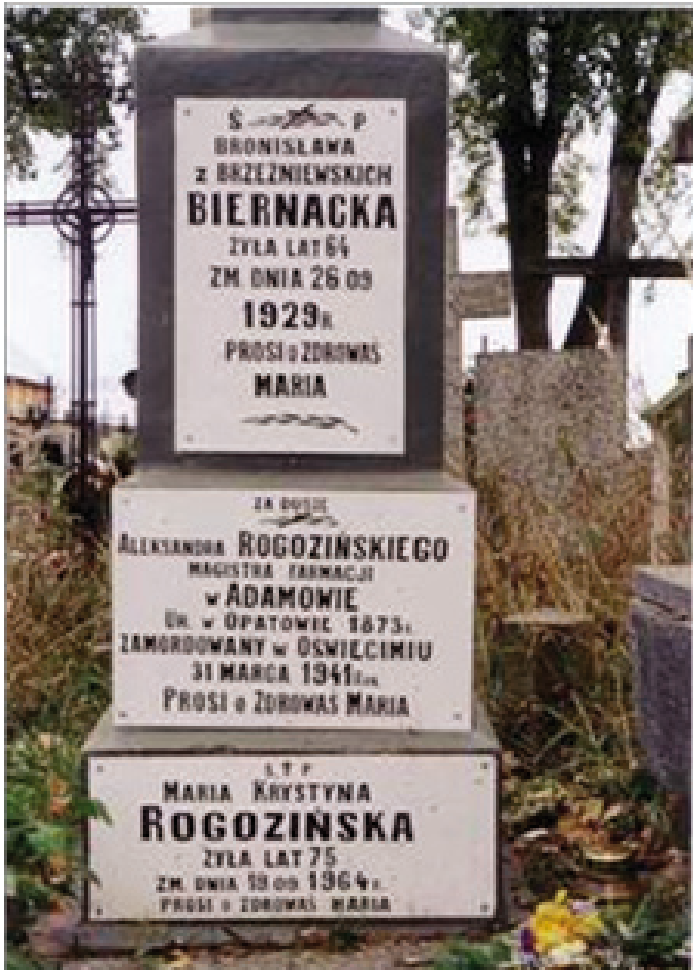

Figure 9. The Tombstone of Bronisława Biernacka (1865-1929), the wife of Aleksander Biernacki (18731941) and her daughter Maria Rogozińska (1889-1964) nee Biernacka - married to Aleksander Rogoziński

Figure 8. Students of the Faculty of Pharmacy University of Tartu (1897) - the arrow indicates Aleksander Rogoziński

(source: pharmacy in Adamów archive)

Aleksander Rogoziński married Maria Biernacka in 1905, and moved to Adamów. After the marriage, Aleksander Rogoziński inherited the pharmacy from his mother-in-law Bronisława Biernacka [24]. His pharmacy soon became an important meeting place for social gatherings. Here, there were often discussions about local politics and local administration.
(Aleksander was murdered in Auschwitz by the Nazi in 1941 and his name is commemorated here because he has no known grave) (Source: Photo Marcin Szczygieł, 2004)

\section{Stanisław (1913-1998) and Tatiana Rogozińscy}

Stanisław Rogoziński (1913-1998) was born in Adamów, on May 1, 1913 [6]. He graduated from the National Gymnasium of Bolesław Prus, in Siedlce, on 17 June 1933. In 1937, he began to study at the Faculty of Pharmacy of the University of Warsaw [Fig. 11]. 


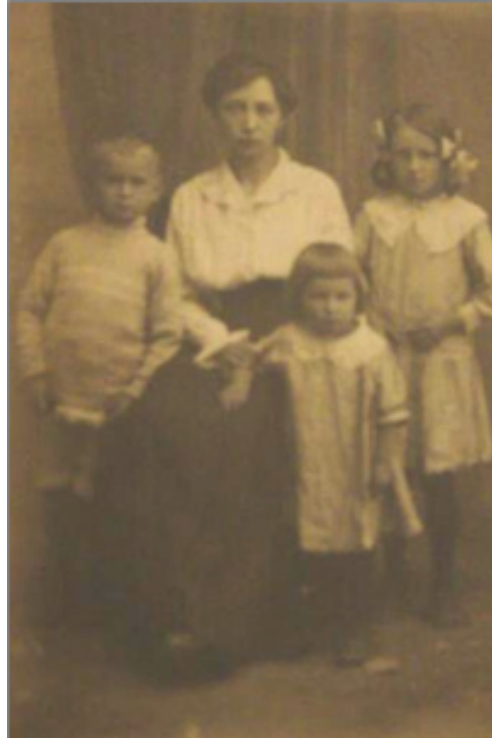

Figure 10. Stanisław Rogoziński (1913-1998) with his mother, Maria Rogozińska (1889-1964) and sisters Marianna and Martyna (Source: Private collection of the Rogoziński's family)

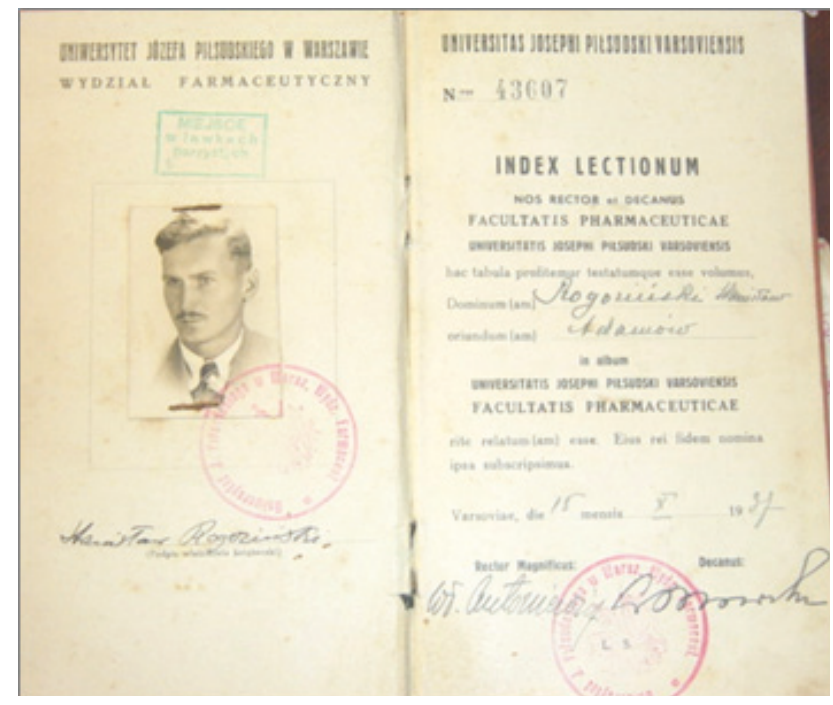

Figure 11. Stanisław Rogoziński when he was a student at Faculty of Pharmacy at Warsaw University

(Source: Private collection of the Rogoziński's family)

When Stanislaw Rogoziński had completed the second year of his university studies, war broke out in September 1939. Called up, during the Nazi invasion of Poland, he fought near Grudziądz. In December 1939, he returned to Adamów and was registered in the Chamber of Pharmacists in Lublin as a pharmacist trainee, undertaking his apprenticeship in his father's pharmacy. He was arrested by the Nazis along with his father in 1940, but he managed to escape, returning home to take care of the practice and his family. In March 1943, he was sent to practice in the pharmacy in Lviv, by the head of the Chamber of Pharmacists. The owner of this pharmacy was Dobrzyński (M. Pharm.). In March 1944, he again returned to Adamów. After the war, in 1946, he returned to his studies, this time as a student at the Jagiellonian University in Crakow [8]. He graduated from the University in 1946, 14 years after passing the matriculation examination [Fig. 12].

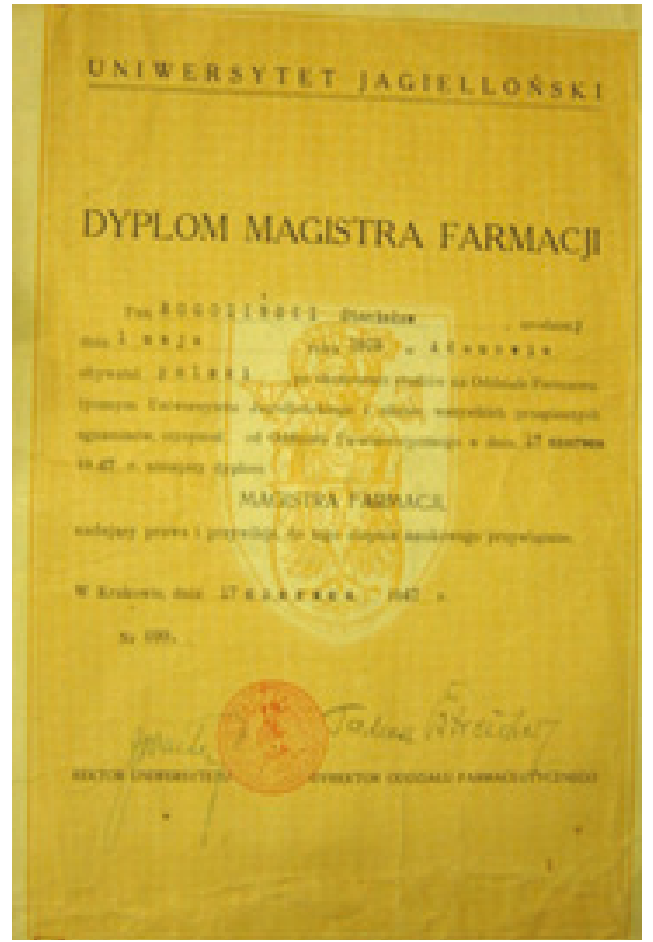

Figure 12. Diploma of Stanisław Rogoziński M. Pharm. (Source: Private collection of the Rogoziński's family)

Once more, he returned to Adamów. On September 8 1947, he married Tatiana Jeryszew (maiden name Sińkowska) [7]. Tatiana was born into a family with Polish roots [10,12, 13], on November 29, 1918, in Cherkasy, a city in the central Ukraine, where her father, Paweł Sińkowski, practiced law. Her family returned to Poland after 1918, and they lived in a village near Kremenets, the place where her parents were born. Paweł Sińkowski died in 1925. After his death, Aleksandra Sińkowska moved to Lutsk. Here, Tatiana and her sister graduated from school, and, here, Tatiana learned to speak French fluently. Her sister became a teacher [12]. In July 1939, Tatiana married Romuald Jeryszew and moved to Włochy, a village near Warsaw. Their son, Bohdan Fransiszek, was born on the $4^{\text {th }}$ of June, $1940[9,13]$. In 1942, she divorced her husband and moved to Adamów, where she initially maintained herself and her child by tutoring the local children in secret. In 1944, following the liberation, she began to work in Adamów's middle school as a French teacher [12]. On September 8, 1947, she married Stanisław Rogoziński. She continued to work as a teacher, and, during her free time, she helped her husband in the pharmacy. On October 22 1949, their son Hubert was born [4]. In 1949, she resigned her position at the middle school, so as to bring up her children and help her husband in the pharmacy [12, 13]. On July 3, 1953, Marcin, the second son of Tatiana and Stanisław Rogoziński, was born [5]. On November 9 1953, Tatiana gained a diploma as a pharmaceutical technician. Tatiana and Stanisław Rogozińscy initially lived in rooms atop their pharmacy at Śniegockich Square. After some time, they moved to their own home on Poprzeczna Street. 


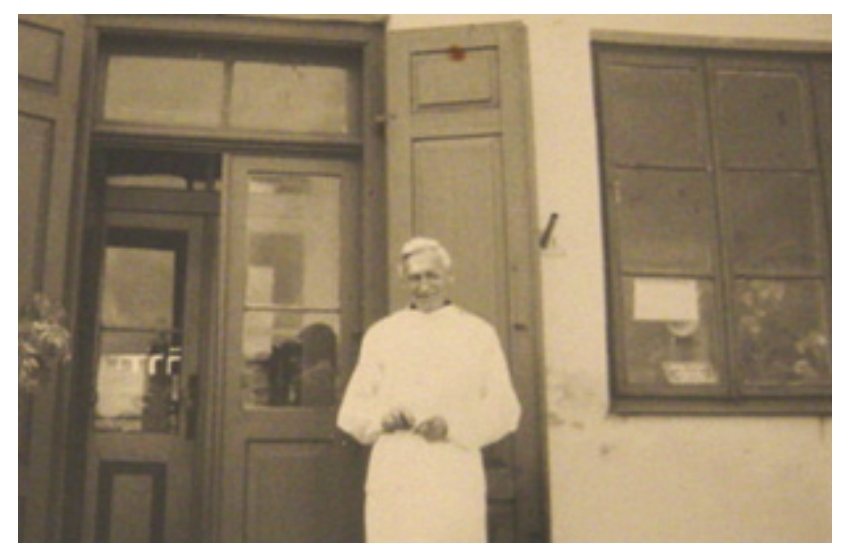

Figure 13. Stanisław Rogoziński in front of his pharmacy (Source: Private collection of the Rogoziński's family)

People from Adamów remember Stanisław Rogoziński as a person who was very punctual. If someone saw him on the way to work in the morning, he used to say: $O h$, Rogoziński is on his way, it must be five minutes to eight, I'll have to hurry, because it is already late [22]. The pharmacy was opened from 8.00 a.m. to 4.00 p.m. During the time when Stanisław lived in rooms atop the pharmacy, he would help people even at night. Indeed, people remember him as a person who was passionate about his work. He practiced his profession for 30 years, not even taking one day off [23].

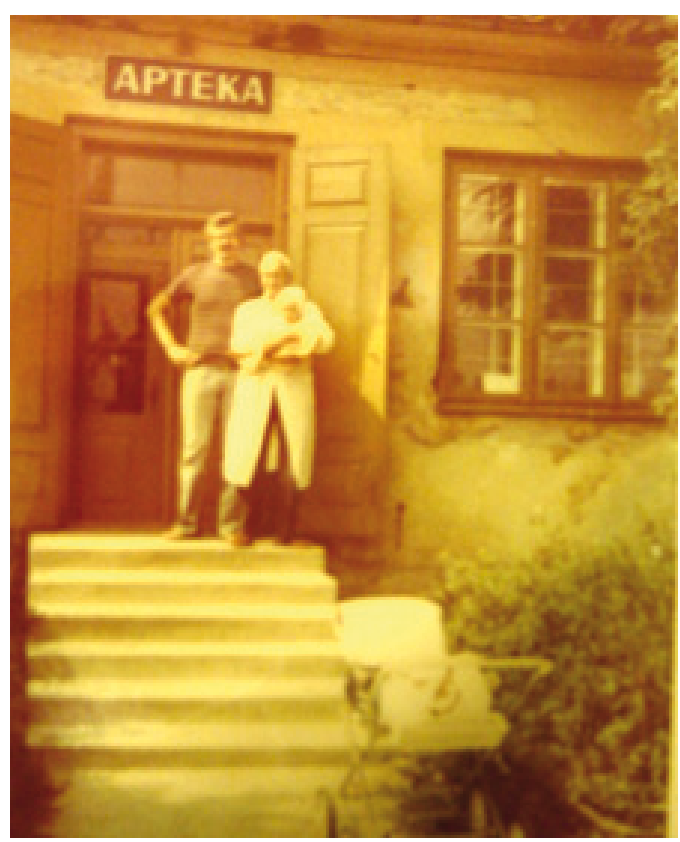

Figure 14. Stanisław Rogoziński with his son and grandchild in front of their pharmacy

(Source: Private collection of the Rogoziński's family)

In the process of the nationalization of the privatelyowned pharmacies in Poland, on January 9, 1951, the pharmacy in Adamów became a common state property. Stanisław Rogoziński became the head of this, doing so til $1978[3,11]$.

Stanisław Rogiziński retired from his job in the pharmacy at the age of 65, on 30 April 1978, but he was still working at the pharmacy till 1982. Krystyna Biadun (M. Pharm) was the head of the pharmacy in the years, 1980-1982.
Since 1982, the head of pharmacy in Adamów has been Marianna Suska-Mazur (M. Pharm). In 1984, she organized an exhibition presenting the history of the local pharmacy. The pharmacy in Adamów is now named after Aleksander Rogoziński, and the names of all former owners and heads of the pharmacy are commemorated [25]. Marianna SuskaMazur bought the pharmacy from Cefarm in 1990, and she relocated it to her house on Kleberga Street. She has had the furnishings and fittings which were used by the Biernacki and Rogoziński family renovated and restored. However, some of the items were donated to the Pharmacy Museum in Lublin.

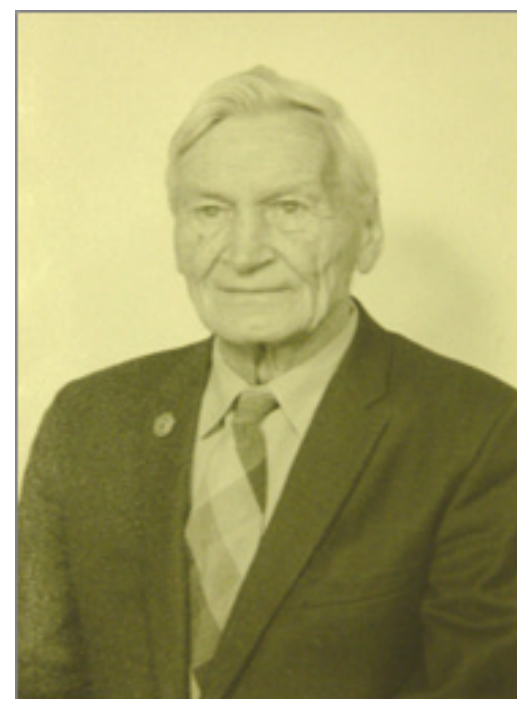

Figure 15. Stanisław Rogoziński at the age of about 75 (Source: Private collection of the Rogoziński's family)

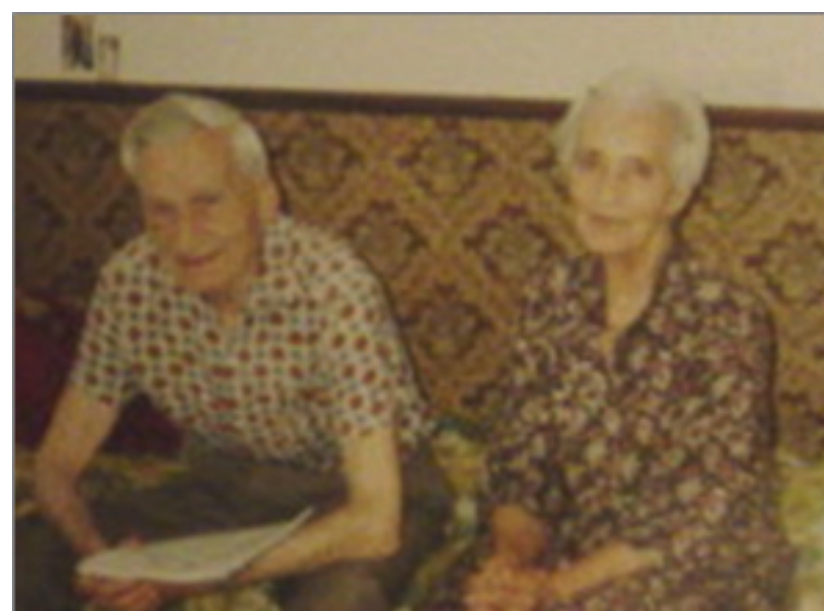

Figure 16. Tatiana and Stanisław Rogoziński in their flat in Łuków where they moved in 1982

(Source: Private collection of the Rogoziński's family)

Tatiana and Stanisław Rogozińscy moved to Łuków in 1982, owing to have more comfortable living in a bigger town. Stanisław Rogoziński left a perfectly kept and prosperous pharmacy in Adamów and gained great respect for himself and his profession [23]. Stanisław Rogoziński died on 28 March 1998. Lots of people attended his funeral. He was buried with firefighter's honors and a helmet was laid on his coffin in the cemetery in Adamów. Tatiana Rogozińska joined him on 6 December 1998. 


\section{The many interests of Stanisław Rogoziński}

Older residents of the town still remember both pharmacists and speak about them with very great respect. Tatiana and Stanisław Rogozińcy took part in lots of social activities. Tatiana was an active participant in the village women's guilds, while Stanisław Rogozińscy was sportsman, fireman and trainer. Indeed, he was the head of the sports club "Sokół" in Adamów, in the years 1955-1968. Such sporting activities gave him lots of satisfaction, and he took special attention towards working with teenagers and in supporting them in their sport initiatives. Stanisław Rogoziński was always considered a man with great presence, and one extremely fit. His neighbor Jadwiga Piszcz described him as a man with:

[...] a graceful figure. She said that even as an old man, he looked like a teenager. Stanistaw Rogiziński used to jog with his dog around the village ponds. Even during winter time he never wear a hat. At the beginning of the spring, he used to dug a hole in the ice to swim in these ponds. He always slept with the window opened. Because of these practices, he was never ill [22].

Even today, a local sport competition is named after him. Stanisław Rogoziński also took part in lots of courses, for example: in tourism (April, 1972, in Sopot). Moreover, he was a member of the Volunteer Fire Brigade (1960), and he belonged to the Front of National Unity. Because of his social activity and dedication towards bettering his society, he was recognized and lauded by the government many times. Among this recognition was the award for exemplary work in Health Care, in January 1966. He also received for his work with teenagers, an award from the Central Committee of Physical Culture and Tourism in 1967. In addition, he was honored to receive the medal 100 Years of Polish Sport, and a silver medal Dedicated to Physical Culture. Furthermore, he was awarded The Sports Cross for Merit. Stanisław Rogoziński also was honoured with The Order of Polonia Restituta on July 20, 1980.

\section{CONCLUSION}

The history of the pharmacy in Adamów is the history of the lives of the Biernacki and Rogoziński family. The history of these families is also the history of Poland's intelligentsia, the social group created during $19^{\text {th }} \mathrm{c}$, who in the times of Russian, German and Austrian partition played important role in the process of creating the national identity of the Polish people. These families was motivated by the desire to better their community and to serve their society. They were true patriots, and it is from this point of view that they treated their work in pharmacy. Thanks to them, the pharmacy in Adamów has become the village's center of cultural and social life. This was done in times of national adversity, when Poland's language, culture and being were maintained and passed on to upcoming generations in secret, when there was little else. And this is why the profession of pharmacy is one of high esteem in the Poland of today.
The most important dates in the history of pharmacy in Adamów:

1882 Aleksander Biernacki established the pharmacy in Adamów, in the building in Śniegocki Square

1905 Aleksander Rogoziński inherited the pharmacy from his mother-in-law, Maria Biernacka

1940 Aleksander Rogoziński was arrested by the Nazis, on 14th September

1940-1946 the pharmacy was in the hands of Maria Rogozińska and her son, Stanisław

1943 In April 1943, a great part of the building in Śniegocki Square was destroyed by fire

1946 Stanisław Rogoziński began work in pharmacy after graduating from the Jagiellonian University in Crakow

1951 in the process of nationalization of privately-owned pharmacies, the pharmacy in Adamów became a common state property

1978 Stanisław Rogiziński retired from his job in the pharmacy at the age of 65 .

1980-1982 Krystyna Biadun M. Pharm was the head of the pharmacy

1982 Marianna Suska-Mazur M. Pharm became the head of pharmacy

1990 Marianna Suska-Mazur M. Pharm bought the pharmacy from Cefarm and moved the pharmacy to her house on Kleberga Street.

\section{REFERENCES}

1. Abramczyk S., Z dziejów Adamowa i okolic. Przyczynek do dziejów pogranicza Mazowsza, Podlasia i Lubelszczyzny; Martynia-Bonik A., Skazany na wierność Polsce, Życie Warszawy, addition Historia i życie 05 1992, 16-17.

2. Aleksandrowicz P., Diecezja Siedlecka czyli Podlaska $w 150$ rocznice erekcji (1818-1968). Przyczynki i materiały do dziejów Diecezji Siedleckiej czyli Podlaskiej, Siedlce, 1971.

3. Archives of PZF Cefarm Lublin, Personal files of Stanisław Rogoziński, Retirement Certificate of Stanisław Rogoziński.

4. Archives of PZF Cefarm Lublin, Personal files of Stanisław Rogoziński, Copy of the birth certificate of Hubert Rogoziński.

5. Archives of PZF Cefarm Lublin, Personal files of Stanisław Rogoziński, Copy of the birth certificate of Marcin Rogoziński.

6. Archives of PZF Cefarm Lublin, Personal files of Stanislaw Rogoziński, Copy of the birth certificate of Stanisław Rogoziński.

7. Archives of PZF Cefarm Lublin, Personal files of Stanisław Rogoziński, Marriage certificate of Stanisław and Tatiana Rogoziński.

8. Archives of PZF Cefarm Lublin, Personal files of Stanisław Rogoziński, Personal questionnaire of Stanisław Rogoziński.

9. Archives of PZF Cefarm Lublin, Personal files of Tatiana Rogozińska, Copy of the birth certificate of Bohdan Franciszek Jeryszew.

10. Archives of PZF Cefarm Lublin, Personal files of Tatiana Rogozińska, Copy of the birth certificate of Tatiana Rogozińska.

11. Archives of PZF Cefarm Lublin, Personal files of Tatiana Rogozińska, Retirement Certificate of Tatiana Rogozińska.

12. Archives of PZF Cefarm Lublin, Personal files of Tatiana Rogozińska, Curriculum vitae written by Tatiana Rogozińska.

13. Archives of PZF Cefarm Lublin, Personal files of Tatiana Rogozińska, Personal questionnaire of Tatiana Rogozińska.

14. Diploma of Aleksander Rogoziński M. Pharm., private collection of Marianna Suska-Mazur - the owner of the pharmacy in Adamów.

15. Dzyr S., Osiński T., Parafia Adamów i jej duszpasterze, Lublin, 2008, 44-45.

16. http://www.adamow.eu/index.php?option=com_content\&view=ar ticle\&id=6\&Itemid=9, available 8.04.2015. 
17. Gumowski M., Pieczęcie i herby miejscowości województwa lubelskiego, Lublin, 1959, 15.

18. ID card of Aleksander Rogoziński, private collection of the Rogoziński's family.

19. Kus J., Lokacja miasta Adamowa w 1539 roku. Zeszyty Historyczne Towarzystwa Przyjaciół Adamowa i Okolic, zeszyt 1.

20. Lubelskie - Wielka Księga miast i gmin, Lublin 2000, 182.

21. Majewski J., Adamów i okolica. Szkic monograficzny rodzinnych stron Henryka Sienkiewicza, Łuków, 1929, 7.
22. Memories of Jadwiga Piszcz 22.04.2003, unpublished.

23. Memories of inhabitants 20.02.2015, unpublished.

24. Notarial deed in Russian of 18 June 1908 specifying conditions for taking over the pharmacy by Aleksander Rogoziński after the death of Aleksander Biernacki (collections of family).

25. Romanowski H., Uroczystości nadania imienia Aleksandra Rogozińskiego aptece w Adamowie, Farmacja Polska,1984, 696.

26. Żabicki J., Leksykon zabytków architektury Lubelszczyzny i Podkarpacia, 2010, 18. 